\title{
POLA KUMAN DAN UJI KEPEKAANNYA TERHADAP ANTIBIOTIKA PADA PENDERITA OTITIS EKSTERNA DI POLIKLINIK THT-KL BLU RSU PROF. DR. R. D. KANDOU MANADO
}

\author{
${ }^{1}$ Pingkan Suwu \\ ${ }^{2}$ Constantyn Kountul \\ ${ }^{3}$ Olivia Waworuntu
}

\begin{abstract}
Bagian Mikrobiologi Fakultas Kedokteran Universitas Sam Ratulangi Manado Email: pingkansuwu090141@yahoo.com
\end{abstract}

\begin{abstract}
Otitis externa is an outer ear canal infection divided into acute and chronic forms based on the course of illness. In a study at Polyclinic ENT-TOS at Prof. dr. R. D. Kandou General Hospital Manado in 2011 it was found that from 5297 there were 440 (8.33\%) cases of otitis externa. This study aimed to determine the pattern of bacteria and antibiotic sensitivity in patients with otitis externa in the Polyclinic ENT-TOS, Prof. Dr. R.D. Kandou Hospital Manado during the period December 2012 - January 2013. This study was a descriptive prospective through a sampling technique of patients. Of the 20 samples tested, 18 $(90 \%)$ showed the growth of bacteria, and two samples (10\%) had no growth of bacteria. There were seven types of bacteria found consisting of two samples (10\%) of Branhamella catarrhalis, four samples (20\%) of Staphylococcus epidermidis, two samples (10\%) of Staphylococcus aureus, two samples (10\%) of Acinetobacter anitratus, two samples $(10 \%)$ of Enterobacter aerogenes, four samples (20\%) of Alcaligenes faecalis, two samples $(10 \%)$ of Proteus mirabilis, and two samples $(10 \%)$ of no bacterial growth. The highest sensitivity antibiotic was levofloxacin in 14 samples $(77.78 \%)$, while the highest resistant to antibiotics was ever getting clindamycin in 16 samples $(88.89 \%)$. Conclusion: nearly all of the samples obtained from otitis externa patients in Polyclinic ENT-TOS, Prof. Dr. R.D. Kandou Hospital Manado during the period December 2012 - January 2013 showed bacterial growth. Levofloxacin was the highest sensitive antibiotic while clindamycin and erythromycin were the highest resistant antibiotic among otitis externa patients in ENT-TOS Clinic of Prof. Dr. R.D. Kandou Hospital, Manado
\end{abstract}

Keywords: otitis externa, pattern of bacteria, sensitivity test.

Abstrak: Otitis eksterna adalah infeksi liang telinga luar yang menurut perjalanan penyakit
terbagi atas bentuk akut dan kronis. Pada penelitian di Poliklinik THT-KL RSU Prof. Dr. R.D.
Kandou Manado pada tahun 2011 diperoleh dari 5.297 pengunjung terdapat 440 (8,33\%)
kasus otitis eksterna. Penelitian ini bertujuan untuk mengetahui pola kuman dan uji
kepekaannya terhadap antibiotika pada penderita otitis eksterna di Poliklinik THT-KL BLU
RSU Prof. Dr. R.D. Kandou Manado periode Desember 2012 - Januari 2013 . Penelitian ini
bersifat prospektif deskriptif dan sampel diambil dari pasien Poliklinik THT-KL. Dari 20
sampel yang diuji, didapatkan 18 sampel $(90 \%)$ menunjukkan pertumbuhan bakteri dan dua
sampel (10\%) tidak memperlihatkan pertumbuhan bakteri. Bakteri yang ditemukan tujuh
jenis, terdiri dari Branhamella catarrhalis dua sampel (10\%), Staphylococcus epidermidis
empat sampel (20\%), Staphylococcus aureus dua sampel (10\%), Acinetobacter anitratus dua
sampel (10\%), Enterobacter aerogenes dua sampel (10\%), Alcaligenes faecalis empat sampel
(20\%), Proteus mirabilis dua sampel (10\%), dan tidak ada pertumbuhan bakteri sebanyak dua
sampel (10\%). Simpulan: hampir semua sampel yang diperoleh dari pasien otitis eksterna di 
Poliklinik THT-KL RSU Prof. Dr. R.D. Kandou Manado periode Desember 2012 - Januari 2013 memperlihatkan pertumbuhan bakteri. Antibiotika yang kepekaannya paling tinggi ialah levofloxacin, sedangkan antibiotika yang resistensinya paling tinggi ialah clindamycin an erythromycin.

Kata kunci: otitis eksterna, pola kuman, uji kepekaan.

Otitis eksterna adalah infeksi liang telinga luar yang dapat menyebar ke pina, periaurikular, atau ke tulang temporal. ${ }^{1}$ Menurut perjalanan penyakit, otitis eksterna terbagi atas bentuk akut dan kronis. Bentuk akut secara primer disebabkan oleh bakteri dan ditemukan pada 4 dari 1.000 orang di Amerika Serikat per tahun. Bentuk kronik biasanya disebabkan oleh fungi, reaksi alergi, atau merupakan manifestasi dari dermatitis, dan ditemukan pada $3-5 \%$ populasi. Menurut penelitian yang dilakukan di Amerika Serikat frekuensi otitis eksterna menurun pada usia $>50$ tahun. ${ }^{2}$ Penelitian di poliklinik THT-KL RSU Prof. Dr. R. D. Kandou Manado pada periode Januari Desember 2011 memperlihatkan bahwa dari 5.297 pengunjung terdapat 440 $(8,33 \%)$ kasus otitis eksterna. ${ }^{3}$ Penelitian terhadap pasien otitis eksterna di Poliklinik THT RS. H. Adam Malik Medan melaporkan 1.734 kunjungan baru dimana dijumpai 867 (8,07\%) kasus otitis eksterna. ${ }^{4}$

Faktor-faktor yang mempengaruhi terjadinya otitis eksterna antara lain perubahan derajat keasaman $(\mathrm{pH})$ liang telinga, pengaruh udara, dan trauma ringan misalnya mengorek telinga yang berlebihan atau karena berenang. ${ }^{1}$

Berdasarkan bentuknya otitis eksterna dapat diklasifikasi menjadi otitis eksterna difusa dan otitis eksterna sirkumskripta. Otitis eksterna difusa disebabkan oleh infeksi bakteri patogen, yang paling umum ialah Pseudomonas, Staphylococcus albus, Escherichia coli, dan Enterobacter aerogenes. Bakteri penyebab otitis eksterna sirkumskripta ialah Staphylococcus aureus dan Staphylococcus albus. ${ }^{1}$ Penelitian yang dilakukan di Poliklinik THT-KL RSU Prof. Dr. R.D. Kandou Manado tahun 2011 memperlihatkan kasus otitis eksterna difusa merupakan bentuk otitis eksterna yang terbanyak ditemukan yaitu 374 pasien
$(84 \%){ }^{3}$ Berdasarkan data Poliklinik THT RS Adam Malik didapati 282 kasus $(2,62 \%)$ otitis eksterna difusa dan 585 kasus $(5,44 \%)$ otitis eksterna sirkumskripta. ${ }^{4}$

Terapi antibiotik yang diberikan dalam pengobatan otitis eksterna amoxicillin clavulanate dan ciprofloxacin yang efektif terhadap Pseudomonas. Pengobatan otitis eksterna perlu ditangani dengan tepat, sesuai dengan pola kuman pada pasien untuk menghindari terjadinya komplikasi. ${ }^{5,6}$

\section{METODOLOGI}

Penelitian ini bersifat deskriptif prospektif. Pengambilan sampel dari pasien otitis eksterna di Poliklinik THT-KL BLU RSU Prof. Dr. R.D. Kandou Manado. Kriteria inklusi ialah pasien otitis eksterna yang bersedia dilakukan pemeriksaan telinga bagian luar. Krieria eksklusi ialah pasien otitis eksterna yang sudah mengonsumsi antibiotika. Pemeriksaan sampel dilakukan di Laboratorium Mikrobiologi RSU Prof. Dr. R.D. Kandou Manado. Penelitian ini dilakukan selama dua bulan Desember 2012 - Januari 2013. Variabel penelitian ialah usia dan jenis kelamin, serta bakteri dalam sekret telinga dan sensitivitas terhadap antibiotika. Data didapatkan dari data rawat jalan pasien dan hasil pemeriksaan laboratorium dengan pewarnaan gram dan uji sensitivitas.

\section{HASIL PENELITIAN}

Pada penelitian yang dilakukan bulan Desember 2012 - Januari 2013 ditemukan 20 sampel berupa sekret telinga pasien otitis eksterna yang diambil dengan cara swabbing dari 20 pasien yang memeriksakan diri di Poliklinik THT-KL BLU RSU Prof. Dr. R. D. Kandou yang yang didiagnosis sebagai otitis eksterna dan 
belum diterapi dengan antibiotika. Hasil penelitian menunjukkan bahwa pasien otitis eksterna terbanyak (10 pasien, $50 \%$ ) pada kelompok usia 18-59 tahun (Tabel 1).

Tabel 1. Distribusi pasien otitis eksterna menurut kelompok usia.

\begin{tabular}{ccc}
\hline Kelompok usia & $\mathrm{N}$ & $\%$ \\
\hline $0-12$ tahun & 6 & 30 \\
$13-17$ tahun & 2 & 10 \\
$18-59$ tahun & $\mathbf{1 0}$ & $\mathbf{5 0}$ \\
$\geq 60$ tahun & 2 & 10 \\
Jumlah & 20 & 100 \\
\hline
\end{tabular}

Dari data penelitian diperoleh pasien otitis eksterna jenis kelamin laki-laki 11 orang $(55 \%)$ dan perempuan sembilan orang $(45 \%)$ (Tabel 2).

Tabel 2. Distribusi pasien otitis eksterna menurut jenis kelamin.

\begin{tabular}{lcc}
\hline \multicolumn{1}{c}{ Jenis Kelamin } & $\mathrm{n}$ & $\%$ \\
\hline Laki-laki & $\mathbf{1 1}$ & $\mathbf{5 5}$ \\
Perempuan & 9 & 45 \\
Jumlah & 20 & 100 \\
\hline
\end{tabular}

Setelah dilakukan pemeriksaan di Laboratorium Mikrobiologi terhadap 20 sampel sekret telinga, didapatkan pertumbuhan bakteri pada 18 sampel; dua sampel tidak memperlihatkan pertumbuhan bakteri. Terdapat tujuh jenis bakteri yang ditemukan, yang terbanyak ialah Alcaligenes faecalis dan Staphylococcus epidermidis (Tabel 3).

Tabel 3. Distribusi bakteri pada sekret telinga pasien otitis eksterna.

\begin{tabular}{lcc}
\hline \multicolumn{1}{c}{ Jenis Kuman } & N & $\%$ \\
\hline Branhamella catarrhalis & 2 & 10 \\
Staphylococcus aureus & 2 & 10 \\
Acinetobacter anitratus & 2 & 10 \\
Enterobacter aerogenes & 2 & 10 \\
Alcaligenes faecalis & $\mathbf{4}$ & $\mathbf{2 0}$ \\
Proteus mirabilis & 2 & 10 \\
Staphylococcus epidermidis & $\mathbf{4}$ & $\mathbf{2 0}$ \\
Tidak ada pertumbuhan & 2 & 10 \\
Jumlah & 20 & 100 \\
\hline
\end{tabular}

Pada uji kepekaan digunakan enam jenis antibiotika yaitu clindamycin, erythromycin, amoxicillin clavulanate, levofloxacin, cyprofloxacin, dan cefriaxone. Hasil penelitian menunjukkan bahwa Staphylococcus aureus, Acinetobacter anitratus, Enterobacteria aerogeness, dan Proteus mirabilis peka terhadap levofloxacin; kuman Acinetobacter anitratus dan Enterobacter aerogenes peka terhadap cefriaxone; kuman Acinetobacter anitratus peka terhadap cyprofloxacin; kuman Enterobacter aerogenes juga peka terhadap amoxicillin clavulanate. Kuman Staphylococcus aureus berespons intermediate terhadap antibiotika cefriaxone dan cyprofloxacin. Kuman Branhamella catarrhalis dan Alcaligenes faecalis resisten terhadap amoxicillin clavulanate; Branhamella catarrhalis, Acinetobacter anitratus, Enterobacter aerogenes, Alcaligenes faecalis, dan Proteus mirabilis resisten terhadap clindamycin; Branhamella catarrhalis, Enterobacter aerogenes, Alcaligenes faecalis dan Proteus Mirabilis resisten terhadap erythromycin; Branhamella catarrhalis resisten terhadap cyprofloxacin juga.

Hasil uji kepekaan memperlihatkan antibiotika yang kepekaannya paling tinggi ialah levofloxacin sebanyak 14 sampel $(77,78 \%)$, sedangkan resistensi kuman yang paling tinggi ditemukan terhadap clindamycin dan erythromycin (Tabel 4).

\section{BAHASAN}

Selama periode penelitian November 2012 - Januari 2013 di Poliklinik THT BLU Prof Dr. R. D. Kandou didapatkan 20 pasien otitis eksterna yang terdiri dari kelompok usia 0-12 tahun enam orang (30\%), 13-17 tahun dua orang $(10 \%), 18-$ 59 tahun 10 orang $(50 \%), \geq 60$ tahun dua orang (10\%). Penelitian Kunarto di Poliklinik THT BLU RSUP Prof. Dr. R. D. Kandou Manado (2009) mendapatkan hasil yang hampir sama yaitu 318 pasien otitis eksterna dengan kelompok usia 18-59 tahun sebanyak 208 orang $(65,41 \%)$, terutama kelompok usia 31-40 tahun (68 orang). ${ }^{7}$ 
Tabel 4. Persentasi kepekaan bakteri terhadap beberapa antibiotika.

\begin{tabular}{llccccccc}
\hline \multirow{2}{*}{ Jenis Kuman } & \multirow{2}{*}{$\mathrm{N}$} & \multicolumn{7}{c}{ Kepekaan (\%) } \\
\cline { 3 - 8 } & & AMC & CRO & CC & CYP & LVX & E \\
\hline Branhamella catarrhalis & 2 & 0 & 0 & 0 & 0 & $\mathbf{5 0}$ & 0 \\
Staphylococcus epidermidis & 4 & 25 & 75 & 0 & 25 & 50 & 0 \\
Staphylococcus aureus & 2 & 0 & 0 & 0 & 0 & $\mathbf{1 0 0}$ & 0 \\
Acinetobacter anitratus & 2 & 50 & 100 & 0 & 100 & $\mathbf{1 0 0}$ & 0 \\
Enterobacter aerogenes & 2 & 100 & 100 & 0 & 50 & $\mathbf{1 0 0}$ & 0 \\
Alcaligenes faecalis & 4 & 0 & 0 & 0 & 75 & $\mathbf{7 5}$ & 0 \\
Proteus mirabilis & 2 & 50 & 50 & 0 & 50 & $\mathbf{1 0 0}$ & 0 \\
\hline
\end{tabular}

Ket: AMC, amoxycillin clavulanate; CRO, ceftriaxone; CC, clindamycin; CYP, cyprofloxacin; LVX, levofloxacin; E, erythromycin.

Penelitian Rupawan di Poliklinik THT BLU RSUP Prof. Dr. R. D. Kandou Manado (2010) juga memperlihatkan hasil yang sama yaitu 20 pasien otitis eksterna kelompok usia 18-59 tahun sebanyak 17 orang $(94,44 \%)$, terutama kelompok usia 31-45 tahun (10 orang). ${ }^{4}$ Hal berbeda ditemukan pada penelitian Roland dan Stroman yang menyatakan bahwa angka kejadian otitis eksterna terbanyak pada kelompok usia 7-12 tahun. ${ }^{8}$

Dari 20 pasien otitis eksterna yang berobat ke Poliklinik THT BLU Prof. Dr. R. D. Kandou Manado dari bulan November 2012 - Januari 2013 ditemukan 11 penderita laki-laki (55\%) dan sembilan perempuan $(45 \%)$. Hasil ini relatif sama dengan penelitian Waitzman di Amerika Serikat (2004) yang mendapatkan perbandingan yang sama antara pasien otitis eksterna laki-laki dan perempuan. ${ }^{9}$ Hasil yang berbeda dikemukakan oleh Palandeng di Poliklinik THT BLU RSUP Prof. Dr. R.D. Kandou Manado (2011) yang mendapatkan pasien perempuan lebih banyak dibandingkan laki-laki, dengan hasil 255 perempuan $(57,96 \%)$ dan 185 laki-laki $(42,04 \%){ }^{3}$ Korelasi antara jenis kelamin dan insidensi otitis eksterna masih harus dibuktikan lebih lanjut dengan jumlah sampel yang lebih besar.

Pada pemeriksaan yang dilakukan terhadap 20 sampel sekret telinga pasien otitis eksterna diperoleh pertumbuhan bakteri pada 18 sampel $(90 \%)$ sedangkan pada dua sampel (10\%) tidak ditemukan pertumbuhan kuman. Terdapat tujuh jenis bakteri yang ditemukan, yang terbanyak ialah Alcaligenes faecalis dan Staphylococcus epidermidis (Tabel 3). Berbeda dengan penelitian Tobing (1984) pada 50 orang pasien otitis eksterna yang mendapatkan bakteri terbanyak ialah Pseudomonas (48\%), diikuti oleh Proteus (18\%), Coliform (16\%), Klebsiella (10\%), dan Staphylococcus $(10 \%) .{ }^{10}$ Hasil penelitian ini juga berbeda dengan penelitian Rupawan di Poliklinik THT BLU RSUP Prof. Dr. R.D. Kandou Manado (2010), yang mendapatkan Staphylococcus aureus empat sampel (20\%), Klebsiella empat sampel (20\%), Pseudomonas aeruginosa tiga sampel (15\%), Staphylococcus albus dua sampel (10\%), Streptococcus dua sampel $(10 \%)$, Coccus gram negatif dua sampel (10\%) dan Enterobacter aerogenes satu sampel (5\%). ${ }^{4}$ Perbedaan tempat, saat, lamanya waktu penelitian, dan jumlah sampel mungkin turut berperan.

Pada uji kepekaan digunakan enam jenis antibiotika yaitu clindamycin, erythromycin, amoxicillin clavulanate, levofloxacin, cyprofloxacin, dan cefriaxone. Hasil uji kepekaan memperlihatkan antibiotika yang kepekaannya paling tinggi ialah levofloxacin sebanyak 14 sampel $(77,78 \%)$, sedangkan resistensi kuman yang paling tinggi ditemukan terhadap clindamycin dan erythromycin 18 sampel (100\%) (Tabel 4). Rupawan (2010) mendapatkan bahwa Staphylococcus albus dan Streptococcus peka terhadap levofloxacin, Staphylococcus aureus peka terhadap cyprofloxacin, Staphylococcus albus peka terhadap 
amoxycilin. Bakteri Coccus gram negatif berespons intermediate terhadap cyprofloxacin, clindamycin, levofloxacin; sedangkan Enterobacter aerogenes berespons intermediate terhadap antibiotika cyprofloxacin dan levofloxacin. Mengenai resistensi terhdap antibiotik, Staphylococcus aureus, Staphylococcus albus, Klebsiella, Enterobacter aerogenes, Streptococcus, dan Coccus gram negatif memiliki resistensi tinggi terhadap tetracyclin; Pseudomonas aeruginosa, Enterbacter aerogenes dan Streptococcus resisten terhadap clindamycin; Staphylococcus albus, Enterobacter aerogenes dan Coccus gram negatif resisten terhadap azitromycin; Enterobacter aerogenes dan Coccus gram negatif resisten terhadap amoxycillin. Hasi penelitian tersebut menunjukkan bahwa tetracyclin tidak cocok digunakan untuk otitis eksterna karena telah menunjukkan tingkat resistensi yang cukup tinggi. ${ }^{4}$

Resistensi kuman terhadap antibiotik merupakan masalah gawat bagi yang bekerja di klinik. Dewasa ini telah dilakukan berbagai usaha untuk meningkatkan pemahaman mengenai mekanisme terjadinya resistensi tersebut. Terbentuknya resistensi dapat dikurangi dengan cara: 1) mencegah pemakaian antibiotik bila tidak jelas dibutuhkan; 2) menghentikan pengunaan antibiotik pada infeksi ringan atau sebagai obat luar; (3) menggunakan antibotik yang tepat dengan dosis yang tepat agar penyembuhan infeksi berlangsung segera dan optimal; 4) menggunakan kombinasi antibiotik yang telah terbukti keefektifannya; dan 5) menggunakan antibiotik yang lain bila ada tanda-tanda bahwa suatu organisme akan menjadi resisten terhadap antibiotik yang digunakan semula. ${ }^{11}$

Dari berbagai mekanisme penyebab timbulnya resistensi terhadap antibiotika sehingga dalam penelitian ini Clindamycin dan Eritromisin tidak cocok digunakan dalam pengobotan penyakit otitis eksterna, karena telah menunjukkkan tingkat resisten yang cukup tinggi.

\section{SIMPULAN}

Berdasarkan hasil penelitian dapat disimpulkan bahwa hampir semua sampel yang diperoleh dari pasien otitis eksterna di Poliklinik THT-KL RSU Prof. Dr. R.D. Kandou Manado periode Desember 2012 Januari 2013 memperlihatkan pertumbuhan bakteri. Antibiotika dengan kepekaan tertinggi ialah levofloxacin, sedangkan antibiotika dengan resistensi tertinggi ialah clindamycin dan erythromycin.

\section{SARAN}

Perbedaan tempat, waktu, serta riwayat pernah mendapatkan terapi antibiotika dapat menyebabkan perbedaan pola kuman. Disarankan pemberian antibiotika untuk pasien otitis eksterna disesuaikan dengan tingkat kepekaan bakteri.

\section{DAFTAR PUSTAKA}

1. Soepardi EA, Iskandar N, Bashlruddin J, Restuti RD. Buku Ajar, Ilmu Kedokteran Telinga Hidung Tenggorok Kepala \& Leher (Edisi Keenam). Fakultas Kedok-teran Universitas Indonesia, hal.60-1.

2. Osguthorpe JD, Nielsen DR. Otitis Externa: Review and Clinical. Retrieved November 1, 2006.

3. Palandeng RW. Otitis eksterna di Poliklinik THT-KL RSU Prof. Dr. R. D. Kandou Manado periode januari 2011Desember 2011 [skripsi]. Manado: Universitas Sam Ratulangi; 2012.

4. Rupawan IK. Pola Kuman dan Kepekaannya terhadap Antibiotika Pada Penderita Otitis Eksterna di Poliklinik THT BLU RSUP Prof. Dr. R. D. Kandou Manado Periode Juni-Juli 2010 [Skripsi]. Manado; Universitas Sam Ratulangi; 2010.

5. Ong YK, Chee G. Infections of the External Ear. Retrieved 2005.

6. Setiabudy R. Pengantar Antibioika; Golongan Kuinolon dan Fluorokuinolon. Farmakologi dan Terapi (Edisi Kelima). Jakarta: Departemen Farmakologi dan Terapeutik Fakultas Kedokteran Universitas Indonesia, 2007; hal. 585-98; 718-22.

7. Kunarto. Otitis Eksterna di Poliklinik THT BLU RSUP Prof. Dr. R. D. Kandou 
Manado periode Januari 2007Desember 2010. Manado: Universitas Sam Ratulangi. 2011.

8. Roland PS, Stroman DW. Microbiology of Acute Otitis Eksterna. July 2002.

9. Seputar Kedokteran. Otitis Eksterna. Diunduh: 19 Januari 2013.
10. Kedel IWM. Hasil Guna Tampon Rivanol Dibanding Tampon Burowi Pada Penderita Otitis Eksterna Diffus Akut. Yogyakarta: 2004.

11. Pelczar MJ, Chan ECS. Dasar-dasar Mikrobiologi. Jakarta: Penerbit Universitas Indonesia, 1988; p.533. 